THE BOSTON

\section{flediral and surniral Jnurnal}

Established in 1828

THURSDAY, SEPTEMBER 15, 1921

\begin{abstract}
Published by The Massachusetts Medical Society under the juriadiction of the following-named committee:

For three years JAMES S. STONE, M.D. HORACE D. ARNOLD, M.D. Ohannare Frothixemu, M.D.

For two years HoMkr GAGE, M.D., Chairman EDWARD O. STREETER, M.D.

For one year WILLIAM H. ROBEY, JR., M.D. ROGER 1. LAR, M.D. ROBERT B. OSGOOD, M.D. EDitorial StafF. David IL EDSALL, M.D. WILTRR B. OLNNaN, M.D. RIID HUXT, M.D. ROEIRT W. LOVETT, M.D. RDWLD H. NICHOLs, M.D. Francis W. Prasody, M.d. JoHar P. SUTHERLUND, M.D. S. BURT WOLBACH, M.D. Grorge R. MiNot, M.D.

WALTER P. BOWERS, M.D., Managing Editor GEORE G. BMITH, M.D., Assistant Editor SUBSCription TRRMs: \$6.00 per year, in advance, postage paid for the United States, $\$ 7.56$ per year for all foreign countries belonging to the Postal Union

Material for early publication should be received not later than noon on Saturday. Orders for reprints must be sent to the printer with galley proof of paper. Upon written request, authors will be furnished tres one hundred eight-page reprints, without covers, or the equivalent in pages in articles of greater length.

The Journal does not hold itself responsible for statements made by any contributor.

Communications should be addressed to The Boston Medical and Surgical Journal, 126 Massachusetts Ave., Boston, Mass.
\end{abstract}

\section{OPENING OF THE PUBLIC SCHOOLS.}

THE present time offers an opportunity for physicians to coöperate with school and health boards, for students will present themselves in varying conditions which call for some investigation. Where real or suspected disability exists the family doctor should welcome the suggestion of the school physician for study of any case among his clientele.

Comparatively few families ask for medical inspection at stated intervals and when a given case provides the opportunity, a diplomatic, courteous lecture on the necessity of professional oversight of children with a full explanation of the dangers often encountered and the great possibility of resulting benefit will lay the foundation for the most effective type of preventive medicine. When people can be convinced that the greater importance lies in anticipating the dangers of disease and the adoption of methods which will help in the development of sturdy children, the dignity of medicine will be more generally recognized.

The problems concerning school children are twofold, affecting the individual child and also his associates, for an apparently healthy carrier may bring grave danger to groups of scholars. Every child with evidence of unhealthy mucous membranes should be submitted to the Schick test. Before very long all children will probably be obliged to have diphtheria susceptibility determined just as vaceination is now required. Where the procedure shall have been universally adopted the mortality of diphtheria will be very much reduced. Students of this problem confidently believe that the ap. plication of present day knowledge will do for diphtheria almost as much as vaccination has done for smllpox.

We should all remember that staying home from school does not kill a child. Mingling with infected children has caused many deaths. Since school life is a necessary feature of civilization the public has a grave responsibility in eliminating every known danger incident thereto. So far as the individual child is concerned, he should not be subjected to the strain of school life as long as he has a cough, abnormal temperature or any evidence of disease which can be remedied or is a source of danger to others.

Coöperate with the school physician!

\section{BOSTON UNIVERSITY SCHOOL OF MEDICINE IN 1921.}

"In certis unitas; in dubiis libertas; in omnibus caritas."

RFORGANiZATION, which for three years has been in progress in Boston University School of Medicine, is practically completed. This does not mean that changes even in the near future may not be made. It simply means that the most radical changes made in the forty-eight years of the school's history have been brought to successful consummation. The reorganization has included the faculty, the curriculum, and the physical properties of the school.

To remove misconceptions it may be permis. sible as a preliminary statement to say that while Boston University School of Medicine was instituted primarily and specifically for the purpose of teaching homeopathic materia medica and therapeutics (subjects not taught elsewhere in New England), it was from the first recognized, and so taught by the late Dr. Conrad Wesselhoft for instance,- that homeopathy was not the whole of medicine, nor even the whole of pharmacotherapeutics. It was considered an exceedingly useful and even an essentially curative form of pharmacotherapy, but from the year of its foundation (1873) the school has included in its curriculum, anatomy, chemistry, surgery, medical jurisprudence. and other subjects not related to homeopathy in the remotest degree. And this has been its policy during the forty-eight years of its existence.

All who are informed realize that the medicine of today (1921) is a very different thing and covers a much wider field of science and art than was the ease with the medicine of half a century ago. Then preventive medicine was 
decidedly impotent. Not only smallpox, but typhoid, typhus, malaria, yellow fever, cholera, bubonic plague, trench fever, beriberi, pellagra, scurvy, rickets, and many other forms of disease are preventable, and the list should continue its beneficent growth until disease has been eradicated.

Then dietetics had not been studied radically; today it is rapidly coming into its own, thera. peutically speaking.

Then surgery with its subdivisions, orthopedies, obstetrics, gynecology and the "specialties," was in its infancy; today surgery is as the crown of therapeutic arts; it is capable of "doing things" and of "getting results."

Then and for preceding centuries, pharmacotherapy was the all-in-all of medicine. For ages its popular method had been antipathic or palliative, at times injuriously so, at other times and in wise hands giving a blessed relief, as is the ease today; but never directly curative. The heteropathic or empirical method has secured but few trophies during its age-long existence; and for over a century the homeopathic method, while curative in principle, and while demonstrating the uselessness of polypharmacy and the undesirability of ponderous posology has been struggling to convince the professional world of its virtues, but as yet has not produced the convincing experimental evidence of its potency (clinical evidence being neither experimental nor convincing).

Then psychotherapy (still in nebulous form), serum-, vaccine-, immuno-, organo-, or glandtherapy, chirotherapy (osteopathy, corrective gymnasties), and calisthenies, hydro-, thermo-, and chemo-therapy, electro- and radio-therapy, were practically unheard of, but now all have their advocates and adherents, and are to be reckoned with as parts of the therapeutic field.

Then the art of diagnosis was only beginning to be what it is today, viz., the big and all-important connecting link between the therapeutic arts and the fundamental medical sciences. These sciences themselves also have made great strides during the half century under consideration.

In keeping with these briefly ontlined changes in medical arts and sciences, the curriculum at Boston University School of Medicine gradually extended its scope until its horarium included 4680 or more hours. Its methods of teaching gradually changed, laboratory and clinic more or less replacing the lecture. Now, however, the curriculum has been rearranged and classified into seven departments, each with its responsible head. and each with its share of the 4000 -hour schedule which has been adopted for the horarium. No essential subject has been omitted, but concentration, with logical and methodical classification, has been the order of the day. The ehanges, however, have been less marked in the matter of the curriculum than in the manner of present- ing it to the student-mind. Here the laboratory and laboratory methods have come very much to the front in anatomy, histology, embryology, biological chemistry, physiology, pharmacology, bacteriology, immunology, pathology and diagnosis, while in the important departments of medicine and surgery with their subdivisions, the clinic, ward walks, and clinical clerkships, have superseded the traditional lecture in the general ratio of two to one. This is in close accord with the most approved pedagogical ideas practised by leading medical schools and upheld by recognized standardizing agencies. It is also quite in accord with the aphorism, "Science knows no creeds," and with the idealism of truth-seekers.

To accommodate much enlarged classes as well as changes in the curriculum and methods, the laboratories of the school have all boen made over and new ones added. The chemical, histological and embryological, the physiological and pharmacological laboratories have been enlarged in space, equipment and general facilities by 33 to $50 \%$ so as to supply the needs of classes numbering fifty, or not over sixty. The Museum has been converted into practically a bacterio-pathological laboratory by the installation of baleony and desks for microscopical work, making an entirely new room for teaching purposes. The ready accessibility of museum preparations adds greatly to the facilities of the department.

A large lecture room has been reconstructed and converted into a commodious dissecting room, large enough for a working class of approximately sixty, and specially constructed desks have been added with exceptional illumination for the study of cross sections.

The library has been moved into a former lecture room with abundant daylight, where several large tables furnish seating and study room for about thirty students at one time. The library itself now represents a combination of the libraries of the Evans Memorial, the Main Hospital, and the School, the books, together with selected magazines and journals, being easily accessible.

The chief interest in the reorganization probably centers at this time in the personnel of the faculty and not so much in the old as in the new members. Foremost among these changes, as they are wholly new to the staff, stand three names:

Alexander S. Begg, M.D., recently Demonstrator in Anatomy and Instructor in Histology at the Harvard Medical School, and Assistant Dean of the Post-Graduate School, is to have charge of the Department of Anatomy, Histology and Embryology. His wide experience in teaching, and his acquaintance with general medical education, obtained in administrative work, coupled with his natural abilities, admirably qualify him for the duties he has been willing to assume. 
Frederick Haven Pratt, A.M., M.D., formerly Professor of Physiology in the University of Buffalo and Teaching Fellow in Physiology at Harvard Medical School, author of numerous studies in muscle fibre, etc., has become the head of the Department of Physiology. Dr. Pratt retains, for the time being at least, the original staff of the department, as does Dr. Begg in Anatomy, both believing there is enough work for all, if it be done right.

Walter L. Mendenhall, M.D., from the Medical School of the University of Pennsylvania, formerly Professor of Pharmacology at the Dartmouth Medical School, has undertaken the task of building up a Department of Pharmacology on its strictly scientific side, leaving the therapeutic end chiefly with the clinician, where it belongs. His experience in laboratory experimentation, as a teacher and as a research worker, equips him well for the task. The general idea is to link pharmacology, in the limited sense, with the fundamental medical sciences, and put pharmacotherapeutics where it naturally belongs, among the medical arts.

Even the briefest résumé of the reorganization would be incomplete and unworthy that failed to recognize the broad and generous spirit of the President of the University and the Board of Trustees, without whose very practical financial support and encouragement. the present elaborate reorganization and program would have been impossible.

The courage and high idealism of the founders of the school; the hopes and faithful struggles of their immediate successors; the freedom from prejudice plus an earnest desire to grow and keep abreast of the day, which marked a later generation; the general independence and self-reliance which has marked the career of the school; and the final amalgamation with and complete adoption of the school, its ideals, traditions and ambitions, by the University, makes this year of reorganization, 1921, the beginning of its forty-ninth year, an epoch of vital importance to the school, the effects of which may radiate in unending circles.

JohN P. SuTherland, M.D.

\section{THE USE OF TOBACCO.}

P. K. Holmes, M.D., head of the Department of Hygiene and Public Health of the University of Kentucky, claims that the effect of the use of tobacco has not been fully comprehended. While he concedes that much that has bieen written against the use of tobaceo is unsound and exaggerated, he contends that there are indications that tobacco is definitely harmful, and cites as examples, that boys who smoke show up more poorly than those who do not and that the smoker upon giving up the habit exhibits better work; again, that an increasingly larger number of business men are getting to feel, that the use of tobacco interferes with efficiency, at least in youths, and that the findings of the Pasteur Institute indicate that the long continued use of minute doses of any poison ulitimately causes harm; further, that athletic trainers require abstinence from tobacco. College men who are users of tobacco are not so efficient as the non-smokers, for at Yale and Amherst non-users gained over the users in height, weight, chest girth, and lung capacity. Now that the alcohol problem has been passed upon by the people in a certain way, some are turning attention to tobacco. Arguments in favor of the drug may ultimately be focused on the need of overwrought systems for some steadying influence, but it will have to be conceded that the great majority of tobacco addicts cannot claim any apparent justifieation for its use on this ground.

Until many more deleterious agencies and customs have been eliminated from human employment, it is quite unlikely that persional liberty will be further encroached upon by laws relating to the use of tobacco, which will go much beyond those restricting sale to youths.

It is quite generally believed that boys and girls should not use tobacco, and in all probaim bility, the habit is acquired too early in life.

Future extension of prohibitory regulations applied to young people would probably meet with endorsement of the profession if a reasonable law could be devised.

\section{A NEW PUBLICATION.}

A small pamphlet has been sold on the streets of Boston under the title "American Infant Hygiene," published as a commercial enterprise to secure coöperation of the public by publicity to help motherhood and infancy.

The owner and publisher is E. A. Gray, with an office at 285 Tremont street, Boston. The reading matter purports to have been taken from publications by the Children's Bureau, U. S. Department of Labor, The American Association for the Prevention of Infant Mortality, The United States Child Bureau, and a copy of the diet list arranged by the Boston Floating Hospital. So far as copies of meritorious articles put forth by reputable organizations are concerned, there is no ground for criticism, if one feels inclined to enter this field of journalism, but in the editorial column there is a plea for the Sheppard-Towner Bill and on the outside back cover pleas for maternity benefits.

The writer was interested to visit the house of this new venture in public health and legislative fields and found the owner of the publication was a free lance without association with organizations or individuals interested in such matters, but who had an ambition to build up a journal dealing more or less directly with health matters. with plans to employ phvsicians who would furnish contributions. He was 